\title{
In Vivo Ex-Vivo Measurement of Crown-Rump and Small Intestinal Length in Nigerian Dogs: A Surgical Measure for Safe Intestinal Resection and Anastomosis
}

\author{
Kisani Iku Aboh ${ }^{1 *}$, Adeyanju John Bayo ${ }^{2}$, Sonfada, Mamman Legbo ${ }^{3}$ and Elsa Tele Abdullahi ${ }^{1}$ \\ ${ }^{1}$ Department of Veterinary Surgery and Theriogenology, University of Agriculture, Nigeria \\ ${ }^{2}$ Department of Veterinary Surgery and Radiology, Sokoto Nigeria, Nigeria \\ ${ }^{3}$ Department of Anatomy, Usmanu Danfodiyo University, Sokoto Nigeria
}

Submission: April 15, 2017; Published: May 05, 2017

*Corresponding author: Kisani Iku Aboh, Department of Veterinary Surgery and Theriogenology,University of Agriculture, Nigeria, Tel: +234 08033745806, Email: abohkisani@yahoo.com

\begin{abstract}
The purpose of this study is to establish the relationship between crown-rump length and small intestinal length and how this can be used to estimate the total small intestinal length in dogs that have to undergo small intestinal resection and anastomosis. Thirteen adult Nigerian dogs with mean body weight of $11.5 \pm 1.5 \mathrm{~kg}$ were used in this study. The animals were premedicated with atropine and xylazine intramuscularly. Anaesthesia was induced with thiopentone sodium intravenously. Access to the abdominal cavity was through the ventral midline abdominal incision. The small intestine was exposed and four measurements were made for each animal and the average small intestinal length was determined. The average length of the small intestine in Nigerian dogs was $247.6 \pm 22.4$ and that of crown-rump length $72.4 \pm 3.8 \mathrm{~cm}$. The small intestinal length was found to be 3.4 times the crown-rump length. These measurements have defined a normal range for crown-rump and small intestinal lengths in Nigerian dogs and may be of importance in planning surgical and nutritional interventions.
\end{abstract}

Keywords: Anastomosis; Resection; Treitz ligament; Intestine

\section{Introduction}

Crown-rump length is the measurement of the length of human or animal embryos and foetuses from the top of the head (crown) to the bottom of the buttock (rump). It can be used to estimate gestational age [1] and the length of the crownrump is the same as that of umbilical cord of a fetus whereas the intestinal length is the measurement of the length of the intestine. It is done to know the transit time of agents ingested. Its measurement can also provide useful information in disease conditions where multiple bowel resections are envisaged [2,3]. The small intestine is designed to perform various functions such as nutrient absorption, barrier function, injury response and immunologic reservoir [4-7]. It is therefore, endowed with unique anatomic features, which provide it with a massive surface area, a diversity of cell types, and a complex neural network to coordinate these functions [8-12]. The length of the small intestine and its physiologic condition determine the capacity for absorption of nutrients which ensures the survival of the individual animal [2]. The small intestine in adults is reported to be longer than that of infants and this excess length confers adults with the advantage of adjusting favourably to physiological and pathological challenges [3]. The small intestine given the role it plays in absorption and secretion of enzymes can be said to be the numero uno of the gastrointestinal tract. The aim of this study was to determine the crown-rump and small intestinal length with intent for identifying anatomical land marks for intestinal resection and anastomosis is in Nigerian dogs.

\section{Materials and Methods}

Thirteen adult Nigerian dogs with average body weight of $11.2 \pm 2.8$ were used for the study. The dogs were bought from breeders and housed in kennels within the Veterinary Teaching Hospital for four weeks for acclamatization.

\section{Anaesthesia and Surgical procedure}

Each animal was premedicated with Atropine $(0.04 \mathrm{mg} / \mathrm{kg})$ and xylazine $(1 \mathrm{mg} / \mathrm{kg})$ intramuscularly. Induction of anaesthesia was done using thiopentone Sodium $(10 \mathrm{mg} / \mathrm{kg}$ ) intravenously. Endotracheal intubation was instituted. Standard sterile preparation for laparotomy was done. Each animal was weighed and the Crown-rump length was measured using standard 
flexible tape rule.

The ventral midline abdominal approach was used to access the abdominal cavity. The ventral abdomen of each animal was aseptically prepared for surgery. The incision was made through the skin, subcutaneous tissue and linea alba. The peritoneal stab incision was then extended with scissors. The intestinal loops were then exteriorized. The duodenum which is the first part of the small intestine was traced from its beginning at the pylorus and all the three parts of the small intestinal tract were identified. The duodenocolic ligament at the caudal duodenal flexure was severed to free the duodenum. A sterile drip infusion set with both end cut was used to measure the small intestinal length insitu. The measurement was done beginning from the duodenum, just at the distal end of the pancrease to 5\% level [13]. the ileocolic junction. After each measurement, the drip set used was placed on a sterile calibrated ruler and the value of each measurement was determined in centimetres $(\mathrm{cm})$ and recorded. Four measurements were done in each animal and the average intestinal length was determined for each animal. The average small intestinal length of each dog was divided by its crown-rump to find the proportion. The total average of the proportion was evaluated and considered as the ratio to be used. The small intestinal length was divided by the crown-rump length of animal to get the ratio of intestinal length to the crownrump length.

\section{Statistical Analysis}

Student t-test was used to compare the crown-rump length and intestinal length. The level of significance was determined at

\section{Results}

Table 1: Crown-rump length, intestinal length and ratio of crown-rump to intestinal length of Nigerian local dogs.

\begin{tabular}{|c|c|c|c|c|c|}
\hline Dog & Weight (Kg) & $\begin{array}{c}\text { Crown-Rump Length } \\
\mathbf{( C m )}\end{array}$ & $\begin{array}{c}\text { Intestinal Length } \\
\mathbf{( C m )}\end{array}$ & $\begin{array}{c}\text { Ratio of Intestinal } \\
\text { Length Over Crown- } \\
\text { Rump Length (Cm) }\end{array}$ & $\begin{array}{c}\text { Ratio of Crown-Rump } \\
\text { Length to Intestinal } \\
\text { Length (Cm) }\end{array}$ \\
\hline 1 & 14 & 2 & 242.2 & 3.4 & 0.3 \\
\hline 2 & 11 & 76 & 243.6 & 3.2 & 0.3 \\
\hline 3 & 7 & 71 & 238.5 & 3.4 & 0.3 \\
\hline 4 & 7 & 71 & 233.2 & 3.3 & 0.3 \\
\hline 5 & 10 & 71.5 & 267.6 & 3.7 & 0.3 \\
\hline 6 & 10 & 71.5 & 248.7 & 3.5 & 0.3 \\
\hline 7 & 12 & 71 & 258.7 & 3.6 & 0.3 \\
\hline 8 & 12 & 71 & 239.5 & 3.4 & 0.3 \\
\hline 9 & 14 & 80.5 & 282.4 & 3.5 & 0.3 \\
\hline 10 & 9 & 67 & 221.1 & 3.3 & 0.3 \\
\hline 11 & 9 & 67 & 202.5 & 3 & 0.3 \\
\hline 12 & 15 & 76 & 276.9 & 3.6 & 0.3 \\
\hline
\end{tabular}

\begin{tabular}{|c|c|c|c|}
\hline 13 & 15 & 76 & \\
\hline Mean & $11.2 \pm 2.8$ & $72.42 \pm 3.8$ & 24 \\
\hline
\end{tabular}

be 6 d But since the ratio of crown-rump length to intestinal length is
$24.42 \pm 0.2$ $0.3 \mathrm{~cm}$, it shows that the small intestinal length is three times

The crown-rump length, intestinal length, ratio of intestinal length to crown-rump, intestinal length, ratio of intestinal length to crown-rump length and inverse ratio of intestinal length to crown-rump are presented in Table 1 . The crown-rump length of the dogs ranged from 67 to $80.5 \mathrm{~cm}$ with the average length of $72.4 \pm 3.8 \mathrm{~cm}$. However, the intestinal length of the dogs ranged from 202.5 to $282.4 \mathrm{~cm}$ with average length of $247.6 \pm 22.4 \mathrm{~cm}$. Ratio of intestinal to crown-rump length is between 3.2 and $3.7 \mathrm{~cm}$ with the average of $3.4 \pm 0.2 \mathrm{~cm}$. But its inverse ratio is generally $0.3 \mathrm{~cm}$.

\section{Discussion}

The obtaining of $72.4 \pm 3.8 \mathrm{~cm}$ of crown-rump length and $247.6 \pm 22.4 \mathrm{~cm}$ of intestinal length show that intestinal length is much longer than crown-rump length. This difference may more than the crown-rump length. These measurements will benefit surgical or nutritional intervention and the success of these depend on accurate measurement of small intestinal length viz-a-viz the crown-rump length $[14,15]$.

There are various methods of measuring the small bowel length such as anatomical or surgical measurement, MR enterography and barium examination using opsometer. However, it was reported that anatomical (surgical) measurements and MR enterography have good high degree of correlation and gives better results compared with barium examination [2,16-18]. In this study, the surgical (anatomical) method of measurement was used and to the best of our knowledge, this is the first report on small intestinal length measurement in Nigerian dogs.

Previous studies on small bowel length in humans showed 
variability between individuals which was attributed to subject type (cadaver vs living), methods of measurement and subject characteristics [19]. Therefore to reduce the influence of variability on our measurement, four measurements were taken for each small bowel length and the average was determined. The intestine in Alsatian dogs is reported to be about five times the body (crown to rump) length $[10,20]$ with the small intestine constituting $80 \%$ of this length [20]. This by calculation means that the small intestine is four times the crown-rump length. However, in this study, the small intestinal tract was found to be 3.4 times the crown-rump length in Nigerian dogs. This could be due to breed, nutritional, environmental and genetic factors.

\section{Conclusion}

The length of the small intestine is 3.4 times higher than the crown-rump length as against 5 times reported in Alsatian breed of dogs.

\section{Acknowledgement}

I would like to thank Dr. Saganuwan, S.A for his assistance during the preparation of this manuscript.

\section{References}

1. Ohuma EO, Papageorghiou AT, Villar J, Altman DG (2013) Estimation of gestational age in early pregnancy from crown-rump length when gestational age range is truncated: the case study of the INTERGROWTH21st Project. BMC Medical Research Methodology 13: 151.

2. Sinha R, Trivedi D, Murphy PD, Fallis S (2014) Small-intestinal length measurement on MR Enterography: Comparison with In Vivo Surgical Measurement. AJR 203: 274-279.

3. Weaver LT, Austin S, Cole TJ (1991) Small intestinal length: A factor essential for gut adaptation. Gut 32: 1321-1323.

4. Brown CD (2012) Small Intestine. In: Tobias KM, Johnston (Eds.), Veterinary Surgery, Small Animal. Elsevier Saunders, Netherlands, pp. 1513-1540

5. Schulzke JD, Troger H, Amasheh M (2009) Disorders of intestinal secretion and absorption. Best Practice Research in Clinical
Gastroenterology 23: 395-406.

6. Shaw D, Gohil K, Basson, MD (2012) Intestinal mucosal atrophy and adaptation. World Journal of Gastroenterology 18(44): 6357-6375.

7. Tavakkolizadeh A, Whang EE, Ashley SW, Zinner MJ (2004) Small intestine. In: Brunicardi F, Andersen D, Billiar T (Eds.), Principles of Surgery. ( $9^{\text {th }}$ edn), McGraw-Hill 28-1, New York, USA.

8. Tavakkoli A, Ashley SW, Zinner MJ (2015) Small Intestine. In: Brunicardi CF, Andersen DK, Billiar TR (Eds.), Schwartz's principles of surgery. (10 ${ }^{\text {th }}$ edn), Mc Graw Hill Education, USA, pp. 1139-1174.

9. German AJ (2005) Diseases of the small intestine. In: BSAVA manual of canine and feline gastroenterology. pp. 176-202.

10. Grandage J (2003) Functional anatomy of the digestive system. In Slatter D (Ed.), Textbook of small animal surgery. Philadelphia, Saunders, Netherlands, pp. 499-519.

11. Niess JH, Reinecker HC (2006) Dendritic cells in the recognition of intestinal microbiota. Cell microbial 8: 558-564.

12. Neu J, Li N (2003) The Neonatal Gastrointestinal Tract: Developmental Anatomy, Physiology, and Clinical Implications. Neo Reviews 4: 7.

13. Zar JH (2008) Biostatistical analysis. ( $4^{\text {th }}$ edn), Pearson Education, New Delhi, India, pp. 663.

14. Lal S, Teubner A, Shaffer JL (2006) Review article: Intestinal failure. Aliment Pharmacol Ther 24: 19-31.

15. Lu KC, Hunt SR (2013) Surgical management of Crohn's disease. Surg Clin North Am 93: 167-185

16. Nightingale JM, Bartam CI, Lennard-Jones JE (1991) Length of residual small bowel after partial resection: correlation between radiographic and surgical measurements. Gastrointest Radiol 16: 305-306

17. Shatari T, Clark MA, Lee JR, Keighley MRB (2004) Reliability of radiographic measurement of small intestinal length. Colorectal Dis 6: 327-329.

18. Tacchino RM (2014) Bowel Length: Measurement, Predictors and impact on bariatric and metabolic surgery. Surgery for obesity and Related Diseases 11: 328-334.

19. Raines D, Arbour A, Thompson HW, Figueroa-Bodine J, Joseph S (2015) Variation in small bowel length: Factor in achieving total enteroscopy? Digestive endoscopy 27: 67-72.

This work is licensed under Creative

Commons Attribution 4.0 Licens

DOI: 10.19080/JDVS.2017.02.555591

\section{Your next submission with Juniper Publishers} will reach you the below assets

- Quality Editorial service

- Swift Peer Review

- Reprints availability

- E-prints Service

- Manuscript Podcast for convenient understanding

- Global attainment for your research

- Manuscript accessibility in different formats

( Pdf, E-pub, Full Text, Audio)

- Unceasing customer service

Track the below URL for one-step submission

https://juniperpublishers.com/online-submission.php 